\title{
Role of heat-shock factor 2 in cerebral cortex formation and as a regulator of p35 expression
}

\author{
Yunhua Chang, ${ }^{1,8,10}$ Päivi Östling, ${ }^{3,4,8}$ Malin Åkerfelt, ${ }^{3,4,9}$ Diane Trouillet, ${ }^{1,9}$ Murielle Rallu, ${ }^{5}$ \\ Yorick Gitton, ${ }^{6}$ Rachid El Fatimy, ${ }^{1}$ Vivienne Fardeau, ${ }^{2}$ Stéphane Le Crom, ${ }^{7}$ Michel Morange, ${ }^{1}$ \\ Lea Sistonen, ${ }^{3,4}$ and Valérie Mezger ${ }^{1,11}$ \\ ${ }^{1}$ Biologie Moléculaire du Stress and ${ }^{2}$ Génomique de la Levure, Centre National de la Recherche Scientifique (CNRS) \\ UMR8541, Ecole Normale Supérieure, 75005 Paris, France; ${ }^{3}$ Turku Centre for Biotechnology, University of Turku, \\ Åbo Adademi University, 20520 Turku, Finland; ${ }^{4}$ Department of Biology, Åbo Akademi University, 20520 Turku, Finland; \\ ${ }^{5}$ Groupe régulateurs et effecteurs de la neurogenèse and ${ }^{6}$ Groupe de Biologie Cellulaire des Homéoprotéines, Centre \\ National de la Recherche Scientifique (CNRS) UMR8542, Ecole Normale Supérieure, 75005 Paris, France; ${ }^{7}$ Institut National \\ de la Santé et de la Recherche Médicale (INSERM) 368, Ecole Normale Supérieure, 75005 Paris, France
}

Heat-shock factors (HSFs) are associated with multiple developmental processes, but their mechanisms of action in these processes remain largely enigmatic. Hsf2-null mice display gametogenesis defects and brain

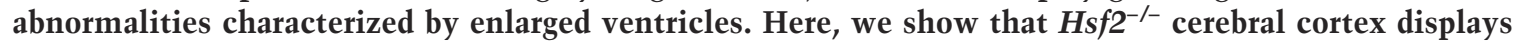
mispositioning of neurons of superficial layers. HSF2 deficiency resulted in a reduced number of radial glia fibers, the architectural guides for migrating neurons, and of Cajal-Retzius cells, which secrete the positioning signal Reelin. Therefore, we focused on the radial migration signaling pathways. The levels of Reelin and Dab1 tyrosine phosphorylation were reduced, suggesting that the Reelin cascade is affected in $\mathrm{Hsf2}^{-/-}$cortices. The expression of $p 35$, an activator of cyclin-dependent kinase 5 (Cdk5), essential for radial migration, was dependent on the amount of HSF2 in gain- and loss-of-function systems. p39, another Cdk5 activator, displayed reduced mRNA levels in $\mathrm{Hsf}^{-/-}$cortices, which, together with the lowered p35 levels, decreased Cdk5 activity. We demonstrate in vivo binding of HSF2 to the p35 promoter and thereby identify p35 as the first target gene for HSF2 in cortical development. In conclusion, HSF2 affects cellular populations that assist in radial migration and directly regulates the expression of $\mathrm{p} 35$, a crucial actor of radial neuronal migration.

[Keywords: Corticogenesis; heat-shock factor; p35-Cdk5; radial cortical migration]

Supplemental material is available at http://www.genesdev.org.

Received September 23, 2005; revised version accepted January 31, 2006.

Heat-shock factors (HSFs) were initially discovered to regulate heat-shock genes and the heat-shock response. The heat-shock response, conserved from yeast to man, is characterized by the induction of heat-shock genes encoding molecular chaperones (for review, see Pirkkala et al. 2001). A unique gene constitutes HSF in yeast, nematode, and fruit fly, whereas a family of four members is present in vertebrates. HSF1 and HSF2 are found in all vertebrate species, while HSF3 is specific for avian species and HSF4 is specific for mammals (Rabindran et al. 1991; Sarge et al. 1991; Schuetz et al. 1991; Nakai and Morimoto 1993; Nakai et al. 1997; Råbergh et al. 2000;

\footnotetext{
${ }^{8,9}$ These authors contributed equally to this work.

${ }^{10}$ Present address: Institut National de la Santé et de la Recherche Médicale (INSERM) U362, Institut Gustave Roussy, 94805 Villejuif, France. ${ }^{11}$ Corresponding author.

E-MAIL mezger@biologie.ens.fr; FAX 33-1-44-32-39-41.

Article and publication are at http://www.genesdev.org/cgi/doi/10.1101/ gad.366906.
}

Hilgarth et al. 2004; Le Goff et al. 2004). In vertebrates, HSF1 is the stress-responsive prototype, which cannot be substituted by any other HSF in stress-inducible hsp gene expression or in acquired thermotolerance (McMillan et al. 1998; Xiao et al. 1999; Zhang et al. 2002).

A developmental role for the HSFs began to emerge when the Drosophila HSF was found to be required for oogenesis and early larval development (Jedlicka et al. 1997). Strikingly, these developmental effects of Drosophila HSF are not mediated by hsp gene induction. The basal expression levels of hsps during embryonic development in mouse are not affected by the lack of HSF1 (Xiao et al. 1999). Therefore, other target genes are likely to be controlled by HSF1 in development. Recently, binding of HSF1 and HSF4 to the FGF-7 promoter with opposing effects on FGF-7 gene expression suggested a competition between these HSFs during mouse lens development (Fujimoto et al. 2004). HSF4 also binds to the promoter of $\gamma$-crystallin, the expression of which is se- 
verely decreased in Hsf4-null lens fiber cells, leading to cataract. Inherited cataract in certain Chinese and Danish families has been associated with a missense mutation in the DNA-binding domain of HSF4 (Bu et al. 2002).

HSF2 has been considered an orphan member of the HSF family. HSF2 was found to be abundantly expressed and active for DNA binding in mouse stem cells, embryonic carcinoma cells, and during hemin-mediated differentiation of human K562 erythroleukemia cells (Mezger et al. 1989; Theodorakis et al. 1989; Sistonen et al. 1992, 1994; Murphy et al. 1994). HSF2 does not display significant heat-shock element (HSE)-binding activity in most adult tissues (Fiorenza et al. 1995), but is highly active during mouse embryogenesis. To date, no clear correlation between HSF2 and hsp gene expression has been found during development (Mezger et al. 1994a,b; Murphy et al. 1994; Christians et al. 1997; Rallu et al. 1997; Alastalo et al. 1998; Kallio et al. 2002; Wang et al. 2003). The developmental role of HSF2 has been assessed by several gene inactivation strategies. Although one study did not report any effects in HSF2-deficient mice (McMillan et al. 2002), we and others have reported that HSF2 is important for meiosis in both genders (Kallio et al. 2002; Wang et al. 2003). Hsf2 ${ }^{-/-}$mice also display brain abnormalities characterized by enlarged lateral and third ventricles (Kallio et al. 2002; Wang et al. 2003). The developmental defects of the $\mathrm{Hsf2}^{-{ }^{-}}$mice do not seem to be due to altered HSP levels, suggesting the importance of other HSF2 target genes.

Mammalian cerebral corticogenesis follows tightly regulated spatial and temporal patterns of neuronal migration. Post-mitotic neurons, generated in the internal ventricular zone (VZ), move along the radial glia guidance fibers toward the external pial surface. The first wave of post-mitotic neurons generates the preplate (PP), into which the next wave of neurons migrates, forming the cortical plate $(\mathrm{CP})$ that consists of an inner subplate $(\mathrm{SP})$ and an outer marginal zone (MZ). Subsequent waves of post-mitotic neurons bypass the SP and any neuronal layers generated earlier, adopting more superficial positions in the $\mathrm{CP}$ region formed beneath the $\mathrm{MZ}$. The $\mathrm{CP}$ therefore grows in an "inside-out" order, from the innermost layer VI comprising the earliest-born cortical neurons to the outer layer II containing the latest-born neurons (Angevine and Sidman 1961).

Analyses of human disease genes and spontaneous or engineered mutant mice have uncovered several gene products in the regulation of corticogenesis (for reviews, see Gupta et al. 2002; Götz 2003). Reelin is secreted by Cajal-Retzius cells of the MZ, and mutations in the Reelin gene in humans cause lisencephaly with simplified cortical folding (Curran and D'Arcangelo 1998; Gupta et al. 2002). The spontaneous mouse mutant reeler exhibits an inverted organization of the cortical layers and fails to split the PP (Lambert de Rouvroy and Goffinet 1998). Upon Reelin binding to ApoER2/VLDLR receptors, expressed on migrating neurons, the cytoplasmic adaptor Dab1 becomes phosphorylated on tyrosine residues (Hiesberger et al. 1999; Howell et al. 1999; Bock and Herz
2003). Perinatal lethality due to widespread defects in neuronal migration during CNS development is evident in mice deficient for cyclin-dependent kinase 5, Cdk5 (Ohshima et al. 1996). In contrast to the reeler phenotype, the PP splitting is preserved in $C d k 5^{-/-}$mice, but later-born neurons stack up in inverted layers under the SP (Gilmore et al. 1998; Kwon and Tsai 1998). The neuron-specific activity of Cdk5 is regulated by its activating subunits p35 and p39 (Tsai et al. 1994). Mice lacking p35 are viable and show lamination defects only in the cerebral cortex, while the $p 35^{-/-} p 39^{-/-}$mice are lethal perinatally (Chae et al. 1997; Ko et al. 2001). During the development of cortex, p35 is predominant but p35 and p39 are expressed equally at birth (Ohshima et al. 2001). The p35-Cdk5 complex in neuronal migration phosphorylates several substrates involved in cell-cell adhesion and cytoskeletal dynamics (for review, see Gupta et al. 2002).

In this study, the role of HSF2 in cerebral corticogenesis was examined. Using $H s f 2^{-/-}$mice, we demonstrate that HSF2 is involved in correct neuronal positioning during cortex formation. Immunohistochemical analyses revealed that HSF2 deficiency has a negative impact on cell populations important for radial neuronal migration. The numbers of radial glia fibers, which provide architectural support for migrating neurons, are reduced in $H s f 2^{-/-}$cortices. Furthermore, the $\mathrm{Hsf}^{-/-} \mathrm{MZ}$ is hypocellular and, correspondingly, the Reelin levels are decreased, affecting the Reelin signaling pathway as evidenced by reduced tyrosine phosphorylation of Dab1. The migrating post-mitotic neurons are affected by the lack of HSF2, as seen by a clear reduction of p35 and p39 leading to lowered Cdk5 activity, all central regulators of radial migration. Using chromatin immunoprecipitation (ChIP), we identified p35 as a direct target gene for HSF2. The multiple levels of radial cortical migration that are affected in the absence of HSF2 suggest novel important functions for this protein in the development of the cortex.

\section{Results}

Dynamic temporal expression pattern of HSF2 in the developing cortex

We previously reported that HSF2-deficient adult brains display structural abnormalities characterized by enlarged ventricles (Kallio et al. 2002). Figure 1A illustrates the variability in the extent of morphological defects in $\mathrm{Hsf2}^{-/-}$postnatal day 19 (P19) brains. In $\sim 80 \%$ of the cases, Hsf2 $2^{-/}$brains show severe enlargement of the hemispheres (Fig. 1A, right panel) compared with the $H s 2^{+/+}$brains (Fig. 1A, left panel), while $\sim 20 \%$ exhibit a moderate enlargement (Fig. 1A, middle panel).

The expression of HSF2 was examined at different stages of corticogenesis using $\mathrm{Hsf2}^{-{ }^{-}}$mice, which have the $\beta$-galactosidase $(\beta$-gal) reporter gene inserted under the control of the endogenous Hsf2 promoter (Kallio et al. 2002). At embryonic day 15.5 (E15.5), $\beta$-gal activity mainly resided in the proliferative zones of $\mathrm{Hsf2}^{-{ }^{-}}$and 
A

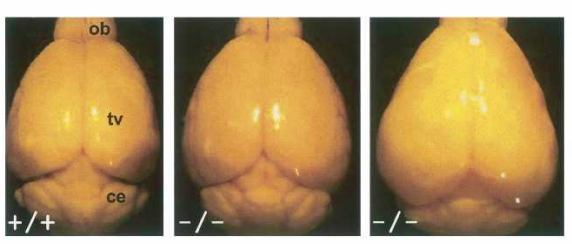

B

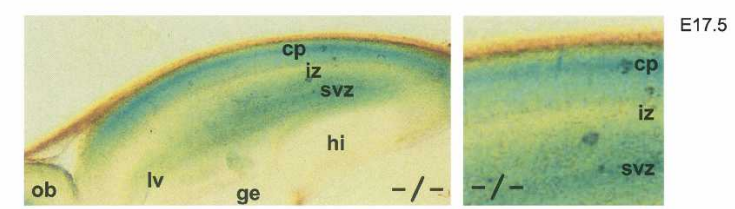

C

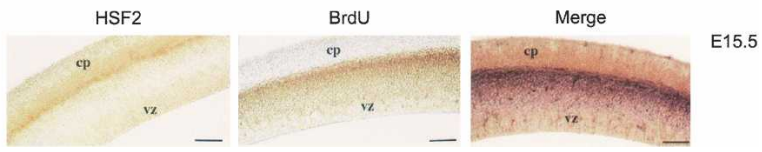

Figure 1. (A) Characterization of $H s f 2^{-/-}$brains. Compared with $H s f 2^{+/+}(+/+), H s f 2^{-/-}$brains (-/-) show enlargement of the hemispheres. Dorsal view of $\mathrm{Hsf2}^{+/+}(+/+, \mathrm{left})$, moderately affected $H s f 2^{-I_{-}}\left(-/-\right.$, middle), and severely affected $H s f 2^{-I_{-}^{-}}$- $_{--}$, right) fixed brains at P19. $(B, C)$ HSF2 is expressed in the CP in late gestation. $(B)$ Parasaggittal vibratome sections of $\mathrm{Hsf2}^{-/-}$ cortices stained for $\beta$-galactosidase activity (blue signal). $\beta$-gal activity not only resided in the VZ and SVZ of $\mathrm{Hsf2}^{-1-}$ developing cortex at E17.5, but was also observed in the CP. Orientation: The rostral part is near the lower left corner. $(C)$ Expression of HSF2 in CP was confirmed in $\mathrm{Hsf2}^{+/+} \mathrm{E} 15.5$ parasaggittal sections by immunohistochemistry in combination with a short pulse of bromodeoxyuridine (BrdU) labeling. Bar, $200 \mu \mathrm{m}$. (ce) Cerebellum, (cp) cortical plate, (ge) ganglionic eminence, (hi) hippocampus, (iz) intermediate zone, (lv) lumenal vesicle, (ob) olfactory bulb, (svz) subventricular zone, (tv) telencephalic vesicle, (vz) ventricular zone.

$\mathrm{Hsf}^{+/-}$developing cortex, similar to earlier stages (from E9.5 to E13.5) (Kallio et al. 2002; Y. Chang, unpubl.)that is, the VZ and subventricular zone (SVZ) - and persisted in the SVZ at E17.5 in $\mathrm{Hsf2}^{+/-}$as in $\mathrm{Hsf2}^{-/-}$embryos (Fig. 1B; data not shown). However, in contrast to earlier stages, $\beta$-gal staining started to be visible at E15.5 in the caudal and medial CP (data not shown) and became more intense at E17.5 (Fig. 1B).

The expression of HSF2 in CP was verified in $\mathrm{Hsf2}^{+/+}$ E15.5 embryos by immunohistochemistry in combination with a short pulse of bromodeoxyuridine (BrdU) labeling, which delimited the proliferating zone (Fig. 1C). In conclusion, HSF2 expression persists throughout corticogenesis in the proliferative zones but is also observed in the CP at late gestation stages. This suggests that HSF2 might have a role not only in the proliferative precursors but also in post-mitotic neurons of the CP.

\section{Normal PP formation in $\mathrm{Hsf} 2^{-/-}$embryos}

To investigate the putative role for HSF2 in corticogenesis, the formation of the PP in E13.5 $\mathrm{Hsf2}^{-/-}$mice was examined. We used two different neuronal markers: The Tuj-1 antibody recognizes class III $\beta$-tubulin expressed in early differentiated neurons (Geisert and Frankfurter 1989), and necdin is expressed in post-mitotic neurons (Niinobe et al. 2000). Since no gross abnormalities were detected in the expression profiles of either Tuj-1 or necdin in $\mathrm{Hsf2}^{-/-}$compared with $\mathrm{Hsf2}^{+/+}$cortex at E13.5 by immunohistochemistry (Fig. 2A) or Western blot (data

A

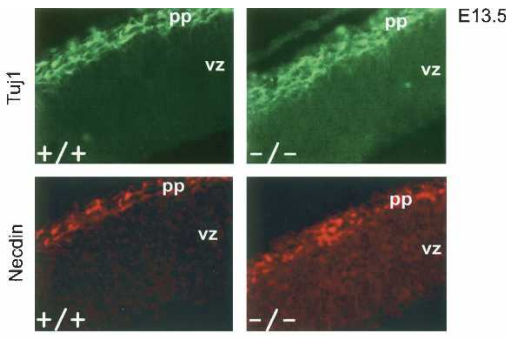

B
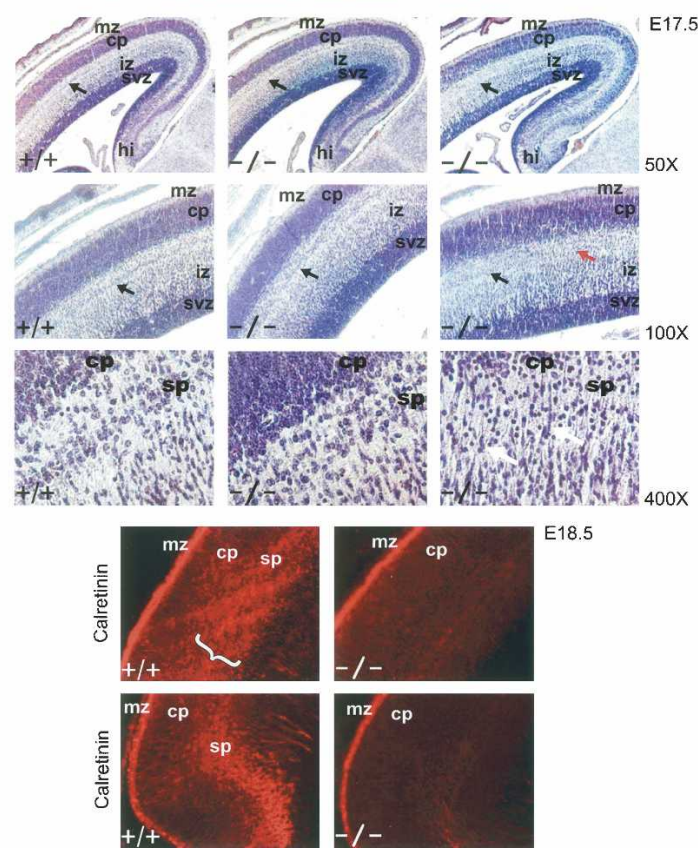

Figure 2. SP disorganization at the end of neurogenesis in $H s f 2^{-/-}$cortex. (A) Immunolabeling of PP by Tuj-1 and necdin antibodies on parasaggittal sections of E13.5 $\mathrm{Hsf2}^{+/+}(+/+)$and $H s f 2^{-/-}(-/-)$cortices. (B) Parasaggittal sections of E17.5 brains were stained with hematoxylin. The numbers on the right side of the figure show the magnification of the image (50x, 100x, and 400x). (Left panel) $H s f 2^{+/+}$. (Middle panel) Moderate phenotype of the $\mathrm{Hsf2}^{-/}$animals, which exhibit disorganized SP (black arrow, magnification 50×, 100×). (Right panel) Severe phenotype of the $H s f 2^{-/-}$animals, where the caudal region is totally devoid of SP (red arrow, 100x), and only a faint SP could be detected rostrally (black arrow, 50x, 100×). Note the numerous trailing cells in the $\mathrm{Hsf2}^{-{ }^{-}-}$cortex at SP level (white arrows, $400 \times$ ). (C) Calretinin staining of the SP (white brackets) was dramatically reduced in parasaggittal sections of the $\mathrm{Hsf2}^{-/}$ neocortex at E18.5. MZ region is overexposed to clearly show the result in the SP. The caudal region (upper panel) was more severely affected than the rostral region (lower panel). (mz) Marginal zone, (pp) preplate, (sp) subplate; other abbreviations are as in Figure 1. 

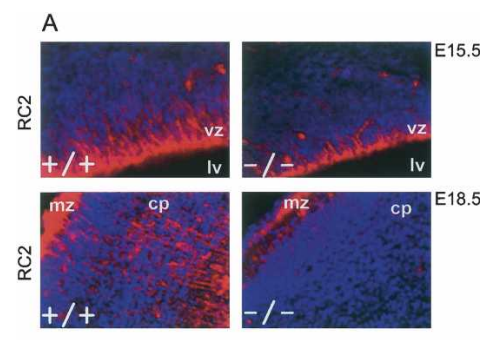

C
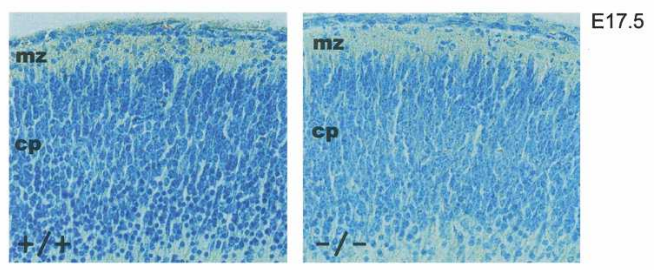

D
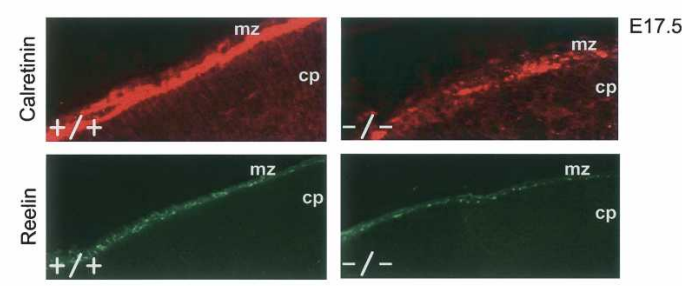

E
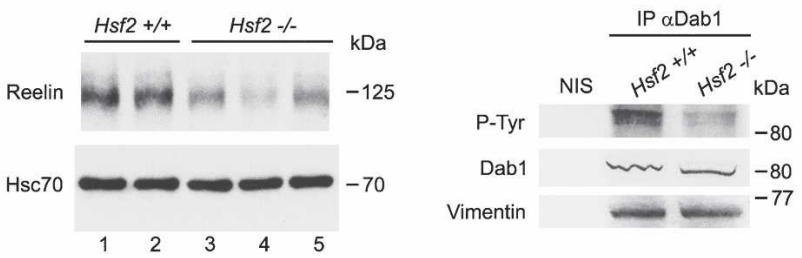

B

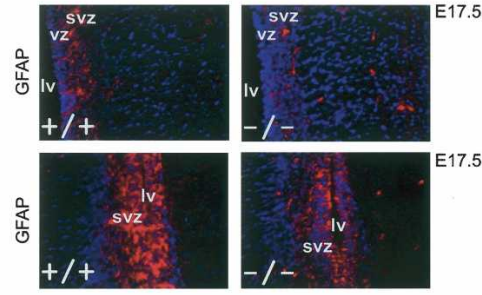

Figure 3. The lack of HSF2 affects radial glia cells and MZ cells. (A) Immunolabeling of radial glia soma by $\mathrm{RC} 2$ (red) in parasaggittal sections of $\mathrm{Hsf2}^{+/+}(+/+)$and $H s f 2^{-/-}(-/-)$cortices at E15.5 and fibers at E18.5. (Blue signal) Hoechst. $(B)$ The presence of astrocytes at E17.5 was analyzed by immunolabeling of astrocytes for GFAP (red) in parasaggittal sections. Orientation is rostral-caudal from top to bottom. (Upper panels) Rostrolateral part of the cortex. (Lower panels) Caudo-medial part of the cortex. (Blue signal) Hoechst. $(C)$ The MZ of $\mathrm{Hsf2}^{-/-}$cortex at E17.5 was hypocellular. Coronal sections of dorsal E17.5 cortices stained with toluidin blue. $(D)$ Lower calretinin immunolabeling of Cajal-Retzius cells in the MZ on parasaggittal sections of caudo-medial region at E17.5 (top panel) and reduction in immunolabeling of Reelin, secreted by Cajal-Retzius cells in $H s 2^{-1-}$ cortex (bottom panel). (E, left panels) Western blotting of CP from individual embryos showed diminished Reelin levels in $\mathrm{Hsf2}^{-/-}$(lanes 3-5) as compared with $\mathrm{Hsf2}^{+/+}$(lanes 1,2). Hsc70 levels were unaffected by the lack of HSF2. (Right, top panel) Decreased tyrosine phosphorylation of Dab1 in pooled caudo-medial $\mathrm{Hsf2}^{-/-}$cortices (reproduced on embryos from three $\mathrm{Hsf2}^{-/-}$and three $\mathrm{Hsf2}^{+/+}$litters). (NIS) Nonimmune serum. (Middle panel) Input material was 1:3 of what was used for IP. (Bottom panel) Loading of equal amounts of protein was assessed by vimentin. Abbreviations are as in Figure 1. not shown), we concluded that PP formation occurs normally during early corticogenesis in $\mathrm{Hsf}^{-{ }^{-}}$embryos.

The SP organization is disturbed at the end of neurogenesis in $\mathrm{Hsf} 2^{-/-}$cortex

PP splitting occurred normally in the cortex of Hsf2-/embryos, and the SP was visible by histological analysis at E15.5 in $\mathrm{Hsf2}^{-\mathrm{I}^{-}}$as well as in $\mathrm{Hsf2}^{+/+}$(data not shown). In contrast, SP started to disappear at E16.5 in $\mathrm{Hsf2}^{-/}$ cortices. At E17.5, Hsf2 ${ }^{-1-}$ embryos displayed SP disorganization of various degrees (Fig. 2B). The histological sections shown in the right panel of Figure $2 \mathrm{~B}$ represent a severe phenotype with prominent SP disorganization in the developing $\mathrm{Hsf2}^{-\mathrm{I}^{-}}$cortex. Even in severely affected mutants, SP was still visible in the rostral part of the telencephalon (Fig. 2B, magnification 100 $\times$, right panel, black arrow), whereas the caudal region was totally devoid of a structure corresponding to SP (Fig. 2B, red arrow, magnification $100 \times)$. The more moderate phenotype exhibited a disorganized SP (Fig. 2B, middle panel). Interestingly, numerous trailing cells were observed in the $\mathrm{Hsf2}^{-/-}$cortex at the SP level (Fig. 2B, white arrows, magnification $400 \times$ ).

Immunostaining for calretinin, a marker for pioneer- ing neurons in SP and in the MZ as well as Cajal-Retzius cells in MZ (Fonseca et al. 1995), was dramatically reduced at the SP level in the Hsf2-/- cortex at E18.5 (Fig. 2C). However, weak calretinin immunostaining was still visible in the rostral part of telencephalon near the olfactory bulbs (Fig. 2C, lower right panel). No evidence for massive apoptosis could be detected by a TUNEL assay in the Hsf2 $2^{-/-}$SP region at stages E14.5-E17.5 (data not shown). The lack of staining of the SP neurons by calretinin at E18.5 (Fig. 2C) confirms that the SP has already disappeared at E17.5 in $\mathrm{Hsf2}^{-{ }^{-}}$caudo-medial cortices (Fig. 2B).

The lack of HSF2 affects two cell populations: radial glia cells and Cajal-Retzius cells

Since the disappearance of SP seemed to be associated with the presence of trailing cells in the SP region (Fig. $2 B$ ), we suspected that radial migration problems might affect the $\mathrm{Hsf2}^{-/-}$cortices and examined two cell populations involved in this process, radial glia cells and CajalRetzius cells. Using the radial glia-specific antibody RC2 (Misson et al. 1988), the $\mathrm{Hsf2}^{-{ }^{-}}$cortex exhibited a prominent reduction in $\mathrm{RC} 2$-positive somae and fibers at E15.5 or E18.5, compared with the $\mathrm{Hsf2}^{+/+}$cortex (Fig. 
3A). Radial glia cells are believed to differentiate into astrocytes at the end of neurogenesis when the neuronal migration is completed (Götz et al. 2002). We labeled E17.5 cortices with the astrocyte-specific marker GFAP (Bignami and Dahl 1974), and $\mathrm{Hsf}^{-/-}$mutants displayed a significantly lower GFAP labeling than $\mathrm{Hsf2}^{+/+}$in VZ and SVZ (Fig. 3B). This suggests that, in the absence of HSF2, the number of radial glia cells is specifically reduced in the cortex, which at least partially could account for the reduction in radial glia fibers and fewer astrocytes.

The MZ of $\mathrm{Hsf2}^{-/-}$cortex at E17.5 was hypocellular in all regions: dorsal (Fig. 3C), lateral, and medial (data not shown). The number of cells in $H s f 2^{-/-}$MZ was medially reduced by $20.8 \%(p<0.05)$, dorsally by $30.6 \%(p<0.04)$, and laterally by $29.2 \%(p<0.06)$ as compared with $\mathrm{Hsf2}^{+/+}$. Round and densely stained nuclei in the $\mathrm{Hsf2}^{+/+} \mathrm{CP}$ appeared to be restricted to the deep CP in the $\mathrm{Hsf2}^{-/-}$ cortex (Fig. 3C), further emphasizing positioning problems. Cajal-Retzius cells reside in MZ and are stained by calretinin (Fonseca et al. 1995). A lower calretinin immunolabeling in $\mathrm{MZ}$ of $\mathrm{Hsf2}^{-/-}$embryos was evident as compared with the $\mathrm{Hsf2}^{+/+}$(Fig. 3D), in agreement with the hypocellularity of the $H s f 2^{-/-} \mathrm{MZ}$. A lower expression of Reelin, which is secreted by Cajal-Retzius cells, was observed in the caudo-medial region of $\mathrm{Hsf2}^{-\mathrm{I}^{-}}$cortex at E17.5 (Fig. 3D, lower panel). The reduced Reelin levels were confirmed in $\mathrm{Hsf2}^{-/-}$individual cortices by Western blotting (Fig. 3E, left panel). The extent to which Reelin expression was decreased was in line with the severity of the morphological changes of the dissected mutant brain. The reduction in the number of MZ cells, accompanied by decreased Reelin expression in $\mathrm{Hsf2}^{-/-}$cortex, is consistent with a decrease in CajalRetzius cells (Bielle et al. 2005).

Next, we investigated the consequences of Reelin reduction on the Reelin signaling pathway by comparing the tyrosine phosphorylation of Dabl in $\mathrm{Hsf}^{-{ }^{--}}$and $\mathrm{Hsf2}^{+/+}$E17.5 cortices. Decreased levels of Dab1 phosphorylation were observed in mutant cortices (Fig. 3E, right panel), suggesting that the Reelin signaling pathway is negatively affected by the lack of HSF2.

\section{Abnormal positioning of neurons from superficial layers of $\mathrm{Hsf2}^{-/-}$cortices}

The effect of HSF2 on the cell populations crucial for radial neuronal migration, radial glia cells, and CajalRetzius cells, suggested that radial migration might be affected in $H s f 2^{-/-}$cortices. To confirm that the initial phases of corticogenesis, PP formation and splitting, were spared in $\mathrm{Hsf2}^{-/-}$cortex (Fig. 2A), we performed BrdU birthdating experiments. The progeny of neural precursors was labeled by BrdU in S phase at E12.5 or E13.5. The positioning of the BrdU-labeled post-mitotic neurons derived from these progenitors at early stages was not affected in $\mathrm{Hsf2}^{-/-} \mathrm{CPs}$ (data not shown). However, the disappearance of SP and the reduced number of radial glia fibers at E17.5 indicated neuronal positioning problems specifically affecting the most superficial lay-

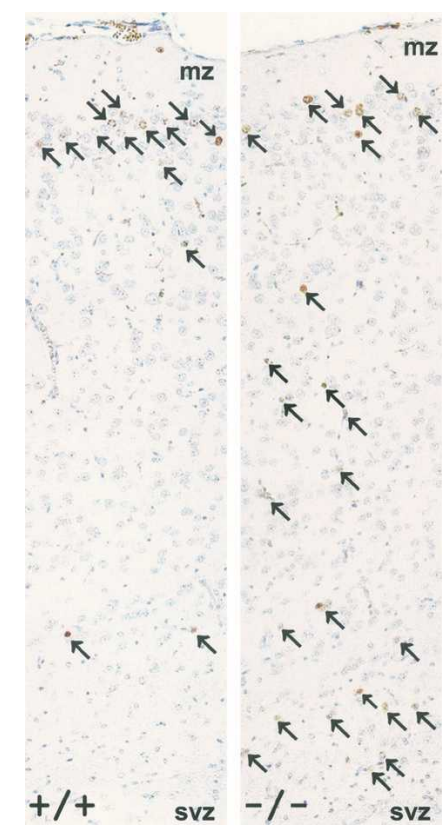

Figure 4. Incorrect positioning of neurons in the superficial layers of $\mathrm{Hsf2}^{-/}$cortices. (Left panel) BrdU birthdating experiments show that the vast majority of BrdU-labeled cells in parasagittal sections of $\mathrm{Hsf2}^{+/+}$cortices are found in superficial layers (arrows). (Right panel) In contrast, although some BrdU-labeled cells were found in superficial layers in $\mathrm{Hsf2}^{-\mathrm{I}^{-}}$cortices (arrows), several BrdU-positive cells were found in abnormal positions deep in the cortex. Abbreviations are as in Figure 2.

ers. To study the positioning of neurons generated in the late corticogenesis, BrdU was injected into pregnant females at E16.5 and the progeny of the labeled cells was followed 1 mo after birth, after the completion of migration. $\mathrm{Hsf2}^{+/+}$cortices showed, as expected, that the vast majority of BrdU-labeled cells were found in superficial layers (Fig. 4, left panel). In contrast, although some BrdU-labeled cells were localized in the same layers in $\mathrm{Hsf}^{-/-}$cortices, a large number of BrdU-positive cells were found deep in the cortex (Fig. 4, right panel), suggesting abnormal positioning of neurons in the $\mathrm{Hsf2}^{-{ }^{-}}$ cortex.

\section{Identification of p35 as a potential target gene for HSF2}

We wanted to establish how HSF2 influences the molecular mechanisms regulating neuronal migration. A clue to the nature of these targets was provided by the model system of human K562 cells (see Introduction). K562 human erythroleukemia cells differentiate toward erythroid lineage upon hemin treatment. During this process, HSF2 levels increase and its DNA binding is activated (Sistonen et al. 1992), but HSF2 is not responsible for the expression of the heat-shock genes (Yoshima et al. 1998; P. Östling, unpubl.). To uncover specific HSF2 target genes, we performed cDNA microarray screening with K562 cell lines stably overexpressing HSF2 (Fig. 5A; Leppä et al. 1997; P. Östling, unpubl.). 
One of the potential target genes identified from this screen was $p 35$, the activator of Cdk5 that is required for cortical lamination (Tsai et al. 1994; Chae et al. 1997). Overexpression of HSF2 was accompanied by a prominent increase in p35 mRNA, which was further enhanced upon hemin treatment (Fig. 5B). Only a minute increase in p35 protein was seen in the hemin-treated cells stably overexpressing HSF2 (Fig. 5C), but it was consistent with elevated levels of the active form of Cdk5 as detected by Tyr 15 phospho-specific antibody (Fig. 5C). The total Cdk5 levels were not markedly altered (Fig. 5C). The increased activity of Cdk5 upon HSF2 overexpression and subsequently elevated p35 expression during hemin treatment was confirmed with a Cdk5 kinase assay (Fig. 5D). Increased phosphorylation of histone $\mathrm{H} 1$ was detected in the HSF2-overexpressing cell line as compared with parental K562 cells.

Reduced expression of p35 and p39 accompanied by attenuated Cdk5 activity in $\mathrm{Hsf}^{-/-}$cortex

Severe defects in cortical lamination are observed in $p 35$ deficient mice, and since the Cdk5-p35 activity has been shown to be crucial for the migration of later-born neurons, we examined their expression in $H s f 2^{-/-}$cortex. Despite variations between individual embryos in the telencephalic p35 expression, E17.5 $\mathrm{Hsf}^{-/-}$telencephalon contained reduced p35 protein levels when compared with $\mathrm{Hsf2}^{+/+}$(Fig. 6A, left panel). No significant changes in Cdk5 levels were observed. However, the active Tyr 15-phosphorylated form of Cdk5 was markedly diminished in individual $\mathrm{Hsf2}^{-/-}$cortices (Fig. 6A, right panel), demonstrating that this signaling cascade is disturbed by the lack of HSF2. Reduced p35 mRNA levels in Hsf2 ${ }^{-/-}$ telencephalon were detected by in situ hybridization on E16.5 Hsf2-/- cortices in the caudo-medial region (Fig. $6 \mathrm{~B}$, left panels). The expression of $p 39$ was also decreased in the caudo-medial region in E18.5 $\mathrm{Hsf2}^{-/-}$cortices (Fig. $6 \mathrm{~B}$, middle panels). In contrast, the Tbr1 mRNA levels, characteristic for the deep layer VI, were not affected (Fig. 6B, right panels). Quantitative RT-PCR confirmed the reduction of $p 35 \mathrm{mRNAs}$ (wild-type/mutant ratio $1.19 \pm 0.04 ; n=6 ; p=0.00134$ ) and $p 39$ (wild-type/mu-

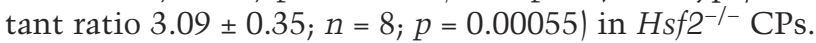
Taken together, these results show that unlike in $p 35^{-/-}$ mice (Ko et al. 2001), reduced p35 levels were not compensated by p39 in Hsf2 ${ }^{-/-}$neocortices.

\section{HSF2 binds in vivo to the proximal regulatory region of the p35 gene}

The results indicated that $p 35$ mRNA is dependent on the amount of HSF2 in HSF2-overexpressing K562 cells and HSF2-deficient cortices, suggesting that $p 35$ could be a novel target gene for HSF2. As HSF2 was previously found to be active mainly in highly proliferative stem cells (Mezger et al. 1989, 1994a,b; Murphy et al. 1994; Christians et al. 1997; Rallu et al. 1997), we verified that HSF2 species present in the CP were active for DNA binding (Fig. 7A). To investigate whether HSF2 regulates

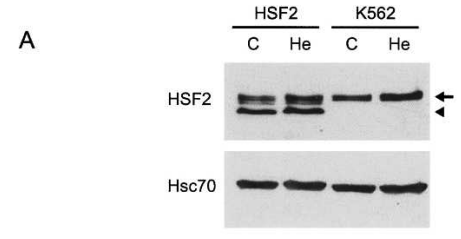

B

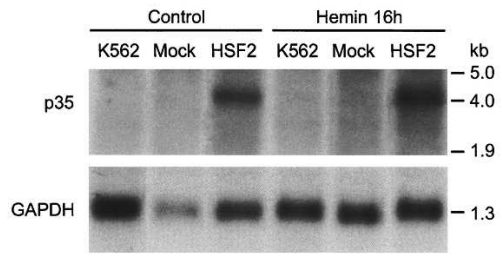

C

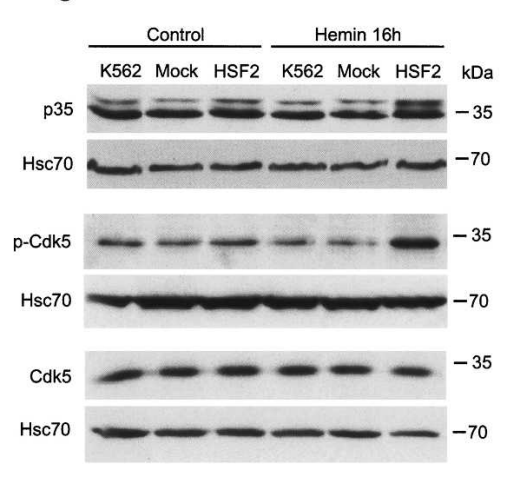

D

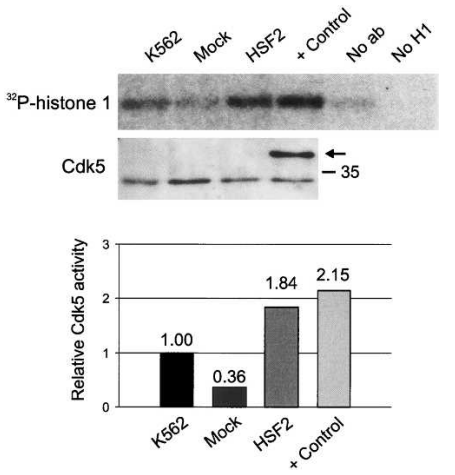

Figure 5. Identification of $\mathrm{p} 35$ as a potential target gene for HSF2. (A) Western blot analysis of K562 cell lines stably overexpressing mouse HSF2 (HSF2) or parental K562 cells (K562) were either left untreated (C) or exposed to hemin $(\mathrm{He})$ for $16 \mathrm{~h}$. Endogenous HSF2 is indicated by an arrow, and exogenous mouse HSF2 is indicated by an arrowhead. Equal loading of protein amounts were assessed by Hsc70. (B) Northern blot analysis: p35 and GAPDH mRNA levels of cell lines stably overexpressing HSF2 (HSF2), mock-transfected cell lines (Mock), or K562 cells (K562) either untreated (control) or treated with hemin for $16 \mathrm{~h} .(C)$ Western blot analysis of p35, Tyr 15-phosphorylated Cdk5, and total Cdk5 levels upon hemin treatement of HSF2-overexpressing cells. $(D)$ Immunocomplex kinase assay shows increased Cdk5 activity in HSF2-overexpressing cells (HSF2). (Top panel) Histone H1 was used as a substrate for the immunoprecipitated Cdk5. (Bottom panel) Similar amounts of Cdk5 were detected in all cell lines (arrow, exogenous Cdk5). The graph shows PhosphorImager quantitation of a representative assay. The measured activities were normalized to the endogenous Cdk5. The relative Cdk5 activity of K562 cells was arbitrarily given the value 1 . 
the $p 35$ gene directly by binding to its promoter, we performed ChIP analysis of CP extracts at E16.5. A 200base-pair (bp) segment within the $p 35$ promoter is sufficient for $\mathrm{p} 35$ expression in rat primary cortical neurons or neurons derived from P19 EC cells (Ross et al. 2002). This region, well conserved between mouse and human, contains a putative HSE close to the main transcription initiation site and two GC-boxes (Fig. 7B). EMSA analyses of CP extracts at E17.5 and E18.5 revealed binding activity on these three sites (data not shown). When immunoprecipitating chromatin from E16.5 cortical extracts with an HSF2-specific antibody, a prominent binding to this region was observed in $\mathrm{Hsf2}^{+/+}$cortex (Fig. $7 \mathrm{C}, \mathrm{D})$, demonstrating that the $p 35$ promoter is a direct target for HSF2 binding. Furthermore, binding of Sp3 to this region was detected in vivo, which is in agreement with the EMSA analysis performed by Ross et al. (2002). Interestingly, impaired binding of Sp3 was consistently observed in E16.5 cortical extracts from $\mathrm{Hsf2}^{-/-}$mice (Fig. 7B,C).

\section{Discussion}

Although HSFs were originally discovered as transcriptional regulators of the heat-shock response, their function in development has been suspected for many years. Recent gene inactivation studies confirmed that HSFs assume developmental roles, independently of hsp gene activation. However, the direct targets of HSF1 and HSF2 have remained to be identified. Our first studies on HSF2 expression in the developing brain suggested that $\mathrm{Hsf2}^{-{ }^{-}}$ brain abnormalities might originate in embryogenesis
(Rallu et al. 1997; Kallio et al. 2002). Here we show that at the end of gestation, HSF2 is expressed and active for DNA binding in the CP from E15.5 until E18.5. This was unexpected, since previously HSF2 had been found to be active only in undifferentiated proliferative cells during mouse development (Mezger et al. 1989, 1994 a,b; Murphy et al. 1994; Christians et al. 1997; Rallu et al. 1997). The timing of HSF2 expression prompted us to investigate how HSF2 might influence cortical development.

The PP formation and the appearance of SP at E14.5 and E15.5 exhibited no gross abnormalities in $\mathrm{Hsf2}^{-/-}$ cortices. Interestingly, in reeler mutant mice, PP splitting does not occur (Lambert de Rouvroy and Goffinet 1998), whereas PP splitting seems intact in $\mathrm{Hsf2}^{-/-}$cortices despite reduced Reelin levels. However, Magdaleno et al. (2002) have shown that limited amounts of Reelin $(10 \%-20 \%$ of the normal endogenous expression) are sufficient to rescue PP splitting in reeler mice. Therefore, the levels observed in $\mathrm{Hsf}^{-\mathrm{I}^{-}}$cortices could be enough to preserve PP splitting. The finding that early corticogenesis is not notably affected in $\mathrm{Hsf2}^{-{ }^{-}}$is in good accordance with the fact that HSF2 is not expressed in the PP or in the CP until E15.5. At E16.5, SP becomes highly disorganized, starts to disappear, and is undetectable or vestigial at E17.5 in $H s f 2^{-/-}$embryos. The disruption does not seem to result from marked apoptotic events, but rather the lack of calretinin-positive cells in $\mathrm{Hsf2}^{-/-}$ cortices implicates differentiation problems. This defect is mainly observed in the caudo-medial part of the cortex and is less pronounced in the rostral part, near the olfactory bulbs.

Our results demonstrate that two cell populations are
Figure 6. The expression of p35 and p39 is reduced in $H s f 2^{-/-}$telencephalon. (A, left panel) In comparison to $\mathrm{Hsf2}^{+/+}$(lanes 1,2), E17.5 Hsf2 ${ }^{-/-}$telencephalon (lanes 3-5) from individual embryos showed reduced p35 protein levels. No significant changes in the level of Cdk5 were detected. Equal amounts of protein were analyzed as indicated by the loading control (Hsc70). (Right panel) The Tyr 15-phosphorylated form of Cdk5 is reduced in $\mathrm{Hsf2}^{-/-}$cortex (lanes 4-6) as compared with $\mathrm{Hsf2}^{+/+}$(lanes 1-3). (B) In situ hybridization: reduction in $p 35$ and p39 mRNA levels (purple signal indicated by a black bar in magnification) at E16.5 and E18.5, respectively, in the caudo-medial region (indicated by box) of $H s 2^{-l-}$ cortices. The dark staining of the IZ does not correspond to specific labeling of p35 or p39 mRNA, as seen in the unlabeled sections in the top panels. (Right panel) The Tbr1 mRNA levels (shown here at E16.5), characteristic for the deep layer VI, were not affected by the lack of HSF2 in the caudo-medial region. (cx) Cortex; other abbreviations are as in Figure 1.

A
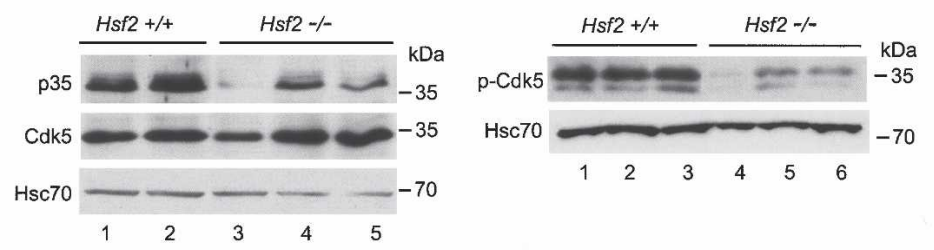

B
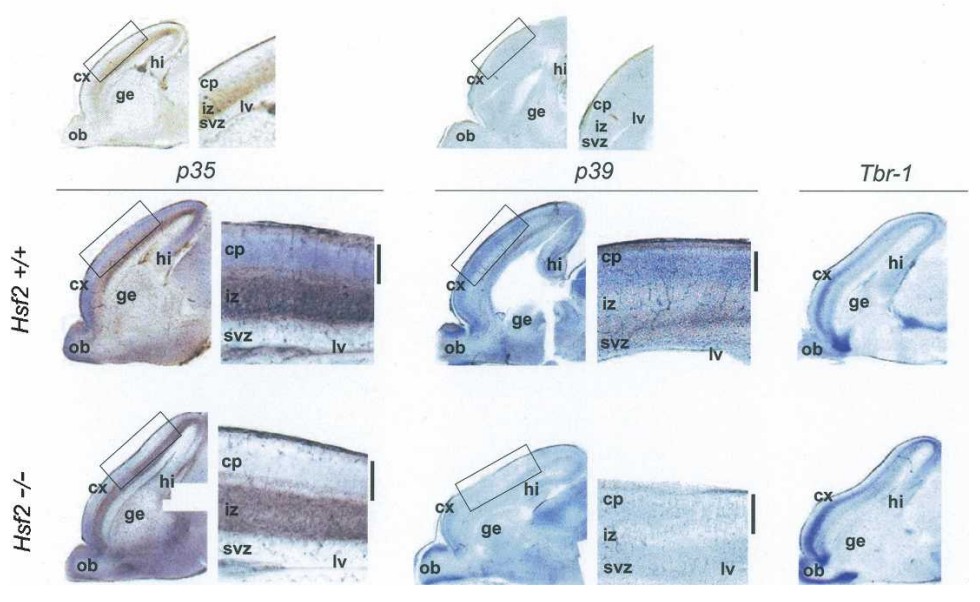
A

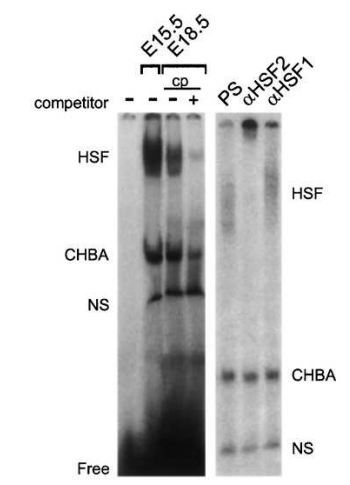

B

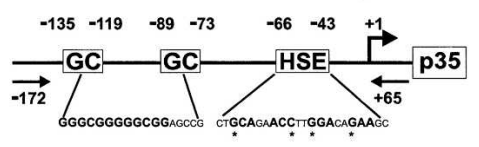

C

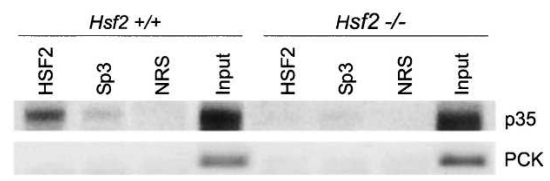

D

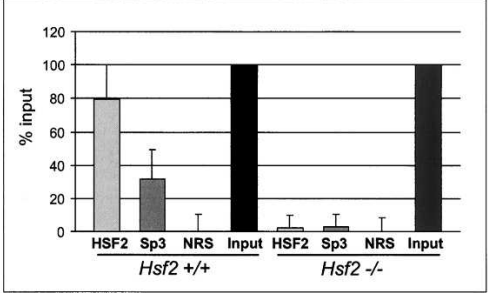

Figure 7. HSF2 binds in vivo to the proximal regulatory region of the p35 gene. (A, left panel) Using EMSA, an HSE-binding complex was detected in the cortex at E15.5 and CP at E18.5. (Right panel) This complex was efficiently supershifted by the HSF2 antibody ( $\alpha$ HSF2), but not by HSF1 antibody ( $\alpha$ HSF 1$)$. (HSF) Specific HSF:HSE complex; (CHBA) constitutive HSEbinding activity; (NS) nonspecific protein-DNA interaction; (Free) free probe; (PS) preserum. (B) Schematic illustration of the proximal p35 promoter region. (GC) GC-boxes; (HSE) putative HSE; (bent arrow) major transcription start site (Ross et al. 2002); (arrows) primers used in amplification step of the ChIP assay. The asterisk marks the key nucleotides required for HSF binding (Fujimoto et al. 2004). (C) ChIP of $\mathrm{Hsf2}^{+/+}(+/+)$and $H_{s f 2^{--}}(-/-)$E16.5 cortical extracts with HSF2, Sp3, and nonspecific (NRS) antibody. Occupancy of the p35 and the phosphoenolpyruvate carboxykinase $(P C K)$ promoters were analyzed. $(D)$ Quantification of three ChIP experiments on pooled cortical extracts from $\mathrm{Hsf2}^{+/+}$and two ChIP experiments from $\mathrm{Hsf}^{-{ }^{-}}$animals, where the input value was arbitrarily set to $100 \%$. The nonspecific antibody value was substracted from the sample value to account for general background.

affected in the $\mathrm{Hsf2}^{-/-}$neocortices. Immunodetection using RC2 revealed a reduction in the radial glia somae and fibers at E15.5 and E18.5. The reduced number of radial glia cells was surprising, since these cells represent a major pool of neuron progenitors (Götz et al. 2002), and no gross abnormalities in neuron generation were detected by either Tuj1 or necdin antibodies at E13.5 or
E17.5. This observation was, however, supported by the fact that $\mathrm{Hsf}^{-{ }^{--}}$cortices displayed a similar reduction in the number of GFAP-positive astrocytes, and that astrocytes are derived from radial glia cells at the end of neurogenesis. Future experiments will determine whether the decrease in radial glia cells is due to the lack of HSF2 in this major pool of progenitors in the VZ. One possibility, which is under investigation, would be that other types of neuronal precursors compensate for the reduction of radial cell progenitors to generate cortical neurons. Moreover, MZ appeared hypocellular, and accordingly the expression of calretinin in the MZ was diminished. The expression of Reelin, which is secreted by Cajal-Retzius cells in MZ, was attenuated in $\mathrm{Hsf2}^{-{ }^{--}}$cortices, suggesting that the lack of HSF2 affects the CajalRetzius cell population in the caudo-medial region. This result together with the diminished tyrosine phosphorylation of a downstream effector Dabl in $\mathrm{Hsf2}^{-/-}$cortices suggests that the Reelin signaling pathway is compromised in our mutants. Reelin signaling directly affects the morphology of radial glia cells, and reeler mutants display a reduction in the extension of radial fibers (Hartfuss et al. 2003). The reduction of radial glia fibers in our mutants might at least partly result from reduced Reelin levels. The reduction of cell populations important for radial neuronal migration, in addition to SP disorganization, prompted us to investigate whether neuronal positioning was disturbed in mutant cortices. BrdU birthdating experiments revealed incorrect positioning of neurons that should have settled in the superficial layers but instead were found in the deep cortical layers. Taken together, our results show that the lack of HSF2 induces incorrect positioning of superficial neurons during cortex formation, suggesting altered migration.

cDNA microarray analysis of K562 cells stably overexpressing HSF2 revealed an increase in p35 mRNA levels, which in turn were down-regulated in $\mathrm{Hsf}^{-/-}$cortex at E16.5. The minor increase in p35 protein levels in hemin-treated K562 stably overexpressing HSF2 resulted in an increased activity of Cdk5. Therefore, it was conceivable that HSF2 influences Cdk5 activity through induction of $p 35$, which could partly explain incorrect positioning of HSF2-deficient neurons from superficial layers. Indeed, we found that the levels of $p 35$, but also p39 and, consequently, the activity of Cdk5 activity were reduced in $\mathrm{Hsf2}^{-{ }^{-}}$cortices. However, these alterations do not recapitulate the entire $p 35^{-/-}$phenotype. Although PP splits normally in $p 35^{-/-}$mice, the subsequent waves of neurons are roughly inverted (Chae et al. 1997; Kwon and Tsai 1998). In Hsf2 ${ }^{-/-}$cortices, PP splitting is intact, but in contrast to $p 35^{-/-}$, only superficial layers are affected. This is in agreement with HSF2 expression starting at E15.5 in post-mitotic neurons of the $\mathrm{CP}$. In addition, $\mathrm{p} 35^{-/-}$mice show more severe defects in the rostral-medial part of the brain, whereas in $\mathrm{Hsf2}^{-}$ -mice $p 35$ levels are reduced mainly in the caudo-medial portion of the developing cortex, where the $\mathrm{Hsf2}^{-/-}$phenotype is most severe in terms of SP disorganization, calretinin expression, and abnormal neuron positioning. The reduction of p35 due to the lack of HSF2 can occur 
only in the area of HSF2 expression, which appears in the caudo-medial region but is absent from the rostral area at E15.5 until E17.5 (data not shown).

We identified within the $p 35$ promoter a putative HSE downstream of two GC-boxes, previously shown to be important for expression in cortical primary neurons (Ross et al. 2002). Sp3 and Sp4 are the major transactivators binding to these two GC boxes in cortical primary neurons. ChIP analysis of E16.5 CP revealed that HSF2 binds to this $p 35$ promoter region in vivo, identifying $p 35$ as a direct target gene for HSF2 in brain development. When examining the mouse and human p39 promoters, we could not find conserved HSEs, suggesting that the mechanism of regulation of $p 39$ by HSF2 is different from that of $p 35$. Recently, HSF2 was reported to regulate chromatin structure by recruiting PP2A, which dephosphorylates and inactivates the condensin complex, to prevent compaction of the hsp 70 promoter during mitosis (Xing et al. 2005). It will be interesting to determine whether HSF2 has a similar mechanism of action in the context of chromatin structure within the $p 35$ promoter. The identification of $p 35$ as the first HSF2 target gene in brain development helps us in our attempts to understand the mechanism by which HSFs regulate gene expression during development. HSF2 not only plays a role in radial glia and $\mathrm{MZ}$ cell populations, but also has effects on the Reelin and Cdk5 signaling cascades that regulate migration of post-mitotic neurons. The Reelin and p35-Cdk5 pathways seem to operate synergistically in the correct positioning of cortical neurons (Ohshima et al. 2001; Beffert et al. 2004). This requires a tight coordination of signaling molecules, to which HSF2 and possibly also other HSFs might contribute by fine-tuning their expression.

\section{Materials and methods}

\section{Mice}

Hsf2 heterozygous mice described in Kallio et al. (2002) were maintained in a C57Bl/6 $\mathrm{N}$ background (backcross 8). Noon on the day of the vaginal plug was considered as E0.5.

\section{Cell culture and experimental treatments}

Human K562 erythroleukemia cells were cultured in RPMI 1640 with $10 \%$ fetal calf serum. K562 cells stably overexpressing HSF2- $\beta$ isoform or the empty vector control (Mock) were maintained as parental K562 cells, with neomycin (G418, 500 $\mu \mathrm{g} / \mathrm{mL}$; Leppä et al. 1997). Hemin (Fluka) was used at a final concentration of $40 \mu \mathrm{M}$ for $16 \mathrm{~h}$.

\section{$\beta$-galactosidase staining, immunohistochemistry, and histological analysis}

$\beta$-galactosidase activity was detected as described (Kallio et al. 2002). For histology, sections were stained with hematoxylin or toluidine blue. For IHC, embryos were fixed in Bouin's fixative for $5-12 \mathrm{~h}$, or in PFA overnight at $4^{\circ} \mathrm{C}$, embedded in paraffin, and cut into $10-\mu \mathrm{m}$ sections. Serial sections were incubated with antibodies for $1 \mathrm{~h}$ at room temperature or overnight at $4^{\circ} \mathrm{C}$ : rabbit anti-GFAP 1:100 (Dako), mouse anti-Tuj-1 1:100, rabbit anti-necdin 1:100, rat BrdU antibody 1:100 (Sigma). For immunostaining on cryosections, brains were fixed in $4 \%$ PFA-PBS overnight at $4{ }^{\circ} \mathrm{C}$, embedded in $0.5 \%$ gelatine $/ 30 \%$ sucrose solution, and cut into $14-\mu \mathrm{m}$ sections. Serial sections were incubated overnight at $4^{\circ} \mathrm{C}$ with mouse anti-RC2 1:10 (IgM, Hybridoma Bank) or anti-calretinin 1:2000 (Swant).

\section{Birthdating experiments}

Pregnant females (two to three) were injected at E12.5, E13.5, or E16.5 with $70 \mu \mathrm{g}$ of BrdU per gram of body weight. E15.5 or P31 brains were fixed overnight in Bouin fixative, paraffin embedded, and cut into $10-\mu \mathrm{m}$ parasagittal sections.

\section{IP and Western blot analysis}

Tissue extracts (TE) and whole-cell extracts (WCE) from K562 cells were prepared as described by Mosser et al. (1988) or Loones et al. (2000). Approximately 20-36 $\mu \mathrm{g}$ of TE or WCE per sample was used for SDS-PAGE. Antibodies: mouse anti-Reelin 1:1000 (clone G10, Calbiochem), mouse monoclonal anti-Dab1 1:400 (H3, gift of A. Goffinet, Université Catholique de Louvain, Brussels, Belgium), mouse monoclonal anti-phosphotyrosine 1:2500 (4G10, Upstate Cell Signaling Solutions), rabbit antiphosphoserine 1:2500 (Chemicon International), rat anti-Hsc70 1:5000 (SPA-815, Stressgen), rabbit anti-Cdk5 1:200 (C-8, sc173, Santa Cruz Biotechnology Inc.), rabbit anti-p-Cdk5 1:200 (sc-12918-R, Santa Cruz Biotechnology Inc.), and rabbit anti-p35 1:200 (N-20, Santa Cruz Biotechnology Inc.). Dab1 was immunoprecipitated from $150 \mu \mathrm{g}$ of total extracts from E17.5 caudomedial neocortex with $10 \mu \mathrm{L}$ of Dabl antibody. Conversely, phosphoproteins were immunoprecitated with $4 \mu \mathrm{L}$ of antiphosphotyrosine antibody (4G10) and blotted against anti-Dab1. The pull-down was performed using Bio-Ademtech magnetic beads coupled to protein $\mathrm{G}$ according to the manufacturer's instructions (Ademtech SA).

\section{Northern blot analysis}

mRNA was isolated from control or hemin-treated K562 cells with the QuickPrep Micro mRNA purification kit (Amersham Biosciences) and separated on an agarose-formaldehyde gel and hybridized with $\left[\alpha-{ }_{-}^{32} \mathrm{P}\right] \mathrm{dCTP}-$ labeled probes: a 775-bp NotIEcoRI human p35 insert (GenBank accession no. AA442853) and a PstI-linearized plasmid for rat GAPDH (pGAPDH) (Fort et al. 1985).

\section{Cdk5 kinase assay}

The IP was performed using $500 \mu \mathrm{g}$ of cell lysate and $5 \mu \mathrm{L}$ of anti-Cdk5 antibody (clone C-8, sc-173, Santa Cruz Biotechnology Inc.) pulled down with Protein A-coated sepharose beads. The immunocomplexes were washed twice with IP buffer and twice with kinase buffer (see Supplemental Material). The Sepharose A pellets were resuspended in $20 \mu \mathrm{L}$ of kinase buffer containing histone $\mathrm{H} 1(100 \mu \mathrm{g} / \mathrm{mL})$. The kinase assay was performed with $5 \mu \mathrm{L}$ of $5 \times$ ATP $\operatorname{mix}\left(1 \mathrm{mCi}\right.$ of $\left[{ }^{32} \mathrm{P}\right]$ per milliliter and $125 \mu \mathrm{M}$ cold ATP in kinase buffer) for $20 \mathrm{~min}$ at $30^{\circ} \mathrm{C}$ and stopped by the addition of $3 \times$ Laemmli buffer. The radioactive signal was detected with a PhosphorImager. The measured activities were normalized to the endogenous C $\mathrm{dk} 5$ levels as detected by Western blotting. The relative Cdk5 activity of K562 cells was arbitrarily given the value 1 .

\section{In situ hybridization}

Embryos were fixed in 4\% PFA and embedded in $0.5 \%$ gelatine/ $30 \%$ sucrose solution and cut into $150-\mu \mathrm{m}$ sections by a vibra- 
tome (Leica). Digoxygenin-labeled riboprobes synthesized from pcDNA3-p35, pcDNA3-p39 (Ko et al. 2001), or pBSE61-Tbr-1 (Hevner et al. 2001) were incubated on sections as described by Wilkinson and Nieto (1993), using digoxygenin alkaline phosphatase-coupled antibodies (Roche) and BM purple AP revelation substrate (Roche).

\section{RT-PCR analysis}

RNAs from the caudo-medial region of E16.5 cortices were purified using RNAqueous-Micro kit (Ambion). Reverse transcription was performed from $500 \mathrm{ng}$ of RNAs using SuperScript first strand Synthesis system for RT-PCR (Life Technologies). Quantitative analysis of the LightCycler data were performed using the Quantitect SYBR green PCR kit (Qiagen) and LightCycler analyzing software. Three genes-the highly expressed $\alpha$-tubulin, the moderately expressed cyclophilin B, and PPOX with low expression-were used for normalization of the results (Dauphinot et al. 2005). For p35 and p39 expression analysis, six and eight independent sets (wild-type and mutant couples), respectively, were analyzed. One set of primers for p39 and two different sets of primers for p35 were used (Harada et al. 2001), adapted to murine $p 35$ sequence (Griffin et al. 2004; Ledee et al. 2005). For primer sequences, see Supplemental Material. $P$ value was determined by Student's $t$-test.

\section{ChIP}

The ChIP protocol was modified from Takahashi et al. (2000). E16.5 cortical tissue was cross-linked with a final concentration of $1 \%$ formaldehyde. Quenching was performed with a final concentration of $125 \mathrm{mM}$ glycine. After cortical cell dissociation, three to five embryonic CPs were lysed in $1 \mathrm{~mL}$ of lysis buffer. Fragmentation of the chromatin samples was performed by sonication with Bioruptor (Diagenode) to an approximate size of $500 \mathrm{bp}$. IP was performed after preclearing with a $50 \%$ slurry of protein G-coated Sepharose beads containing bovine serum albumin (100 $\mu \mathrm{g} / \mathrm{mL}$, Amersham Biosciences) overnight at $4^{\circ} \mathrm{C}$. The following antibodies were used: HSF2 (Sarge et al. 1993), Sp3 (clone D-20, SC-644X Santa Cruz Biotechnology Inc.), and normal rabbit serum (NRS, Jackson Immuno Research Laboratory). Washing of immunocomplexes was performed three times with wash buffer 1 , twice with wash buffer 2, and three times in wash buffer 3 (for washing buffers, see Supplemental Material). Cross-links were reversed by incubating the samples overnight at $65^{\circ} \mathrm{C}$. DNA was purified, and PCR analysis was performed on 1:10 of each ChIP sample using puRe Taq Ready-to-go PCR Beads (Amersham Biosciences). For primer sequences, see Supplemental Material.

\section{Acknowlegdments}

We thank K. Yoshikawa and M. Niinobe for the gift of the necdin antibody, and T. Frankfurter for the Tuj1 antibody. We thank J. Rubenstein for the gift of Tbr1 probe, A. Goffinet for Dab1 antibody, and Li-Huei Tsai for p35 and p39 probes. We are indebted to Rick Morimoto for the gift of HSF2 rabbit polyclonal antibody and constructive discussions. We are thankful for the help and support of the Finnish microarray core facility at Turku Centre for Biotechnology, especially Janika Henriksson, Päivi Junni, Arja Reinikainen, Ilana Saarikko, Rolf Sara, Anne West, and Riitta Lahesmaa. We thank Alessandra Pierani, André Goffinet, Marion Wassef, Sonia Garel, Piotr Topilko, John Eriksson, Cecilia Sahlgren, Hanna-Mari Pallari, and the members of the Sistonen laboratory for helpful discussions and comments. We thank Anne Le Mouël, Rosette Goiame, and Fanny Coulpier for technical help, and Severine Larney from the animal house facilities for animal breeding. This work was supported by grants from the Association pour la Recherche contre le cancer (ARC nos. 4671 and 3609, V.M.), the Academy of Finland, the Sigrid Jusélius Foundation, the Finnish Cancer Organizations, the Finnish Retro Life Insurance Companies (L.S.), and the Turku Graduate School of Biomedical Sciences (P.Ö.).

\section{References}

Alastalo, T.-P., Lönnström, M., Leppä, S., Kaarniranta, K., PeltoHuikko, M., Sistonen, L., and Parvinen, M. 1998. Stage-specific expression and cellular localization of the heat shock factor 2 isoforms in the rat seminiferous epithelium. Exp. Cell Res. 240: 16-27.

Angevine, J.B. and Sidman, R.L. 1961. Autoradiographic study of cell migration during histogenesis of the cerebral cortex in the mouse. Nature 192: 766-768.

Beffert, U., Weeber, E.J., Morfini, G., Ko, J., Brady, S.T., Tsai, L.H., Sweatt, J.D., and Herz, J. 2004. Reelin and cyclin-dependent kinase 5-dependent signals cooperate in regulating neuronal migration and synaptic transmission. J. Neurosci. 24: 1897-1906.

Bielle, F., Griveau, A., Narboux-Neme, N., Vigneau, S., Sigrist, M., Arber, S., Wassef, M., and Pierani, A. 2005. Multiple origins of Cajal-Retzius cells at the borders of the developing pallium. Nat. Neurosci. 8: 1002-1012.

Bignami, A. and Dahl, D. 1974. Astrocyte-specific protein and radial glia in the cerebral cortex of newborn rat. Nature 252: $55-56$.

Bock, H.H. and Herz, J. 2003. Reelin activates SRC family tyrosine kinases in neurons. Curr. Biol. 13: 18-26.

Bu, L., Jin, Y., Shi, Y., Chu, R., Ban, A., Eiberg, H., Andres, L., Jiang, H., Zheng, G., Qian, M., et al. 2002. Mutant DNAbinding domain of HSF4 is associated with autosomal dominant lamellar and Marner cataract. Nat. Genet. 31: 276-278.

Chae, T., Kwon, Y.T., Bronson, R., Dikkes, P., Li, E., and Tsai, L.H. 1997. Mice lacking p35, a neuronal specific activator of cdk5, display cortical lamination defects, seizures, and adult lethality. Neuron 18: 29-42.

Christians, E., Michel, E., Adenot, P., Mezger, V., Rallu, M., Morange, M., and Renard, J.P. 1997. Evidence for the involvement of mouse heat shock factor 1 in the atypical expression of the HSP70.1 heat shock gene during mouse zygotic genome activation. Mol. Cell. Biol. 17: 778-788.

Curran, T. and D'Arcangelo, G. 1998. Role of Reelin in the control of brain development. Brain Res. Brain Res. Rev. 26: 285-294.

Dauphinot, L., Ryle, R., Rivals, I., Tran Dang, M., Moldrich, R.X., Golfier, G., Ettwiller, L., Toyama, K., Rossier, J., Personnaz, L., et al. 2005. The cerebellar transcriptome during postnatal development of the Ts1Cje mouse, a segmental trisomy model for Down syndrome. Hum. Mol. Genet. 14: 373-384.

Fiorenza, M.T., Farkas, T., Dissing, M., Kolding, D., and Zimarino, V. 1995. Complex expression of murine heat shock transcription factors. Nucleic Acids Res. 23: 467-474.

Fonseca, M., Del Rio, J.A., Martinez, A., Gomez, S., and Soriano, E. 1995. Development of calretinin immunoreactivity in the neocortex of the rat. J. Comp. Neurol. 361: 177-192.

Fort, P., Marty, L., Piechaczyk, M., El Sabrouty, S., Dani, C., Jeanteur, P., and Blanchard, J.M. 1985. Various rat adult tissues express only one major mRNA species from the glyceraldehyde-3-phosphate-dehydrogenase multigenic family. 
Nucleic Acids Res. 13: 1431-1442.

Fujimoto, M., Izu, H., Seki, K., Fukuda, K., Nishida, T., Yamada, S., Kato, K., Yonemura, S., Inouye, S., and Nakai, A. 2004. HSF4 is required for normal cell growth and differentiation during mouse lens development. EMBO J. 23: 4297-4306.

Geisert Jr., E.E. and Frankfurter, A. 1989. The neuronal response to injury as visualized by immunostaining of class III $\beta$-tubulin in the rat. Neurosci. Lett. 102: 137-141.

Gilmore, E.C., Ohshima, T., Goffinet, A.M., Kulkarni, A.B., and Herrup, K. 1998. Cyclin-dependent kinase 5-deficient mice demonstrate novel developmental arrest in cerebral cortex. J. Neurosci. 18: 6370-6377.

Götz, M. 2003. Doublecortin finds its place. Nat. Neurosci. 6: $1245-1247$.

Götz, M., Hartfuss, E., and Malatesta, P. 2002. Radial glia cells as neuronal precursors: A new perspective on the correlation of morphology and lineage restriction in the developing cerebral cortex of mice. Brain Res. Bull. 57: 777-788.

Griffin, S.V., Hiromura, K., Pippin, J., Petermann, A.T., Blonski, M.J., Takahashi, S., Kulkarni, A.B., and Shankland, S.J. 2004. Cyclin-dependent kinase 5 is a regulator of podocyte differentiation, proliferation, and morphology. Am. J. Pathol. 165: $1175-1185$

Gupta, A., Tsai, L.H., and Wynshaw-Boris, A. 2002. Life is a journey: A genetic look at neocortical development. Nat. Rev. Genet. 3: 342-355.

Harada, T., Morooka, T., Ogawa, S., and Nishida, E. 2001. ERK induces p35, a neuron-specific activator of Cdk5, through induction of Egr1. Nat. Cell Biol. 3: 453-459.

Hartfuss, E., Förster, E., Bock, H.H., Hack, M.A., Leprince, P., Luque, J.M., Herz, J., Frotscher, M., and Götz, M. 2003. Reelin signaling directly affects radial glia morphology and biochemical maturation. Development 130: 4597-4609.

Hevner, R.F., Shi, L., Justice, N., Huesh, Y., Sheng, M., Smiga, S., Bulfone, A., Goffinet, A.M., Campagnoni, A.T., and Rubenstein, J.L. 2001. Tbr1 regulates differentiation of the preplate and layer 6. Neuron 29: 309-311.

Hiesberger, T., Trommsdorff, M., Howell, B.W., Goffinet, A., Mumby, M.C., Cooper, J.A., and Herz, J. 1999. Direct binding of Reelin to VLDL receptor and ApoE receptor 2 induces tyrosine phosphorylation of disabled-1 and modulates tau phosphorylation. Neuron 24: 481-489.

Hilgarth, R.S., Murphy, L.A., O'Connor, C.M., Clark, J.A., ParkSarge, O.-K., and Sarge, K.D. 2004. Identification of Xenopus heat shock transcription factor-2: Conserved role of sumoylation in regulating deoxyribonucleic acid-binding activity of heat shock transcription factor- 2 proteins. Cell Stress Chaperones 9: 214-220.

Howell, B.W., Herrick, T.M., and Cooper, J.A. 1999. Reelin induced tyrosine phosphorylation of disabled 1 during neuronal positioning. Genes \& Dev. 13: 643-648.

Jedlicka, P., Mortin, M.A., and Wu, C. 1997. Multiple functions of Drosophila heat shock transcription factor in vivo. EMBO J. 16: 2452-2462.

Kallio, M., Chang, Y., Manuel, M., Alastalo, T.-P., Rallu, M., Gitton, Y., Pirkkala, L., Loones, M.-T., Paslaru, L., Larney, S., et al. 2002. Brain abnormalities, defective meiotic chromosome synapsis and female subfertility in HSF2 null mice. EMBO J. 21: 2591-2601.

Ko, J., Humbert, S., Bronson, R.T., Takahashi, S., Kularni, A.B., Li, E., and Tsai, L.H. 2001. p35 and p39 are essential for cyclin-dependent kinase 5 function during neurodevelopment. J. Neurosci. 21: 6758-6771.

Kwon, Y.T. and Tsai, L.H. 1998. A novel disruption of cortical development in p35-/- mice distinct from reeler. J. Comp. Neurol. 395: 510-522.
Lambert de Rouvroy, C. and Goffinet, A. 1998. The reeler mouse as a model of brain development. Adv. Anat. Embryol. Cell Biol. 150: 1-106.

Ledee, D.R., Gao, C.Y., Seth, R., Fariss, R.N., Tripathi, B.K., and Zelenka, P.S. 2005. A specific interaction between muskelin and the cyclin-dependent kinase 5 activator p39 promotes peripheral localization of muskelin. J. Biol. Chem. 280: 21376-21383.

Le Goff, P., Le Drean, Y., Le Peron, C., Le Jossic-Corcos, C., Ainouche, A., and Michel, D. 2004. Intracellular trafficking of heat shock factor 2. Exp. Cell Res. 294: 480-493.

Leppä, S., Pirkkala, L., Saarento, H., Sarge, K.D., and Sistonen, L. 1997. Overexpression of HSF2- $\beta$ inhibits hemin-induced heat shock gene expression and erythroid differentiation in K562 cells. J. Biol. Chem. 272: 15293-15298.

Loones, M.-T., Chang, Y., and Morange, M. 2000. The distribution of heat shock proteins in the nervous system of the unstressed mouse embryo suggests a role in neuronal and non-neuronal differentiation. Cell Stress Chaperones 5: 291305.

Magdaleno, S., Keshvara, L., and Curran, T. 2002. Rescue of ataxia and preplate splitting by ectopic expression of Reelin in reeler mice. Neuron 33: 573-586.

McMillan, D.R., Xiao, X., Shao, L., Graves, K., and Benjamin, I.J. 1998. Targeted disruption of heat shock transcription factor 1 abolishes thermotolerance and protection against heat-inducible apoptosis. J. Biol. Chem. 273: 7523-7528.

McMillan, D.R., Christians, E., Forster, M., Xiao, X., Connell, P., Plumier, J.C., Zuo, X., Richardson, J., Morgan, S., and Benjamin, I.J. 2002. Heat shock transcription factor 2 is not essential for embryonic development, fertility, or adult cognitive and psychomotor function in mice. Mol. Cell. Biol. 22: 8005-8014.

Mezger, V., Bensaude, O., and Morange, M. 1989. Unusual levels of heat shock element-binding activity in embryonal carcinoma cells. Mol. Cell. Biol. 9: 3888-3896.

Mezger, V., Rallu, M., Morimoto, R.I., Morange, M., and Renard, J.P. 1994a. Heat shock factor 2-like activity in mouse blastocysts. Dev. Biol. 166: 819-822.

Mezger, V., Renard, J.P., Christians, E., and Morange, M. 1994b. Detection of heat shock element-binding activities by gel shift assay during mouse preimplantation development. Dev. Biol. 165: 627-638.

Misson, J.P., Edwards, M.A., Yamamoto, M., and Caviness Jr., V.S. 1988. Identification of radial glial cells within the developing murine central nervous system: Studies based upon a new immunohistochemical marker. Brain Res. Dev. Brain Res. 44: 95-108.

Mosser, D.D., Theodorakis, N.G., and Morimoto, R.I. 1988. Coordinate changes in heat shock element-binding activity and hsp70 gene transcription rates in human cells. Mol. Cell. Biol. 8: 4736-4744.

Murphy, S.P., Gorzowski, J.J., Sarge, K.D., and Phillips, B. 1994. Characterization of constitutive HSF2 DNA-binding activity in mouse embryonal carcinoma cells. Mol. Cell. Biol. 14: 5309-5317.

Nakai, A. and Morimoto, R.I. 1993. Characterization of a novel chicken heat shock transcription factor, heat shock factor 3 , suggests a new regulatory pathway. Mol. Cell. Biol. 13: 1983-1997.

Nakai, A., Tanabe, M., Kawazoe, Y., Inazawa, J., Morimoto, R.I., and Nagata, K. 1997. HSF4, a new member of the human heat shock factor family which lacks properties of a transcriptional activator. Mol. Cell. Biol. 17: 469-481.

Niinobe, M., Koyama, K., and Yoshikawa, K. 2000. Cellular and subcellular localization of necdin in fetal and adult mouse 
brain. Dev. Neurosci. 22: 310-319.

Ohshima, T., Ward, J.M., Huh, C.G., Longenecker, G., Veeranna, X., Pant, H.C., Brady, R.O., Martin, L.J., and Kulkarni, A.B. 1996. Targeted disruption of the cyclin-dependent kinase 5 gene results in abnormal corticogenesis, neuronal pathology and perinatal death. Proc. Nat1. Acad. Sci. 93: 11173-11178.

Ohshima, T., Gilmore, E.C., Herrup, K., Brady, R.O., Kulkarni, A.B., and Mikoshibaka, K. 2001. Synergistic contributions of cyclin-dependant kinase5/p35 and Reelin/Dab1 to the positioning of cortical neurons in the developing mouse brain. Proc. Nat1. Acad. Sci. 98: 2764-2769.

Pirkkala, L., Nykänen, P., and Sistonen, L. 2001. Roles of the heat shock transcription factors in regulation of the heat shock response and beyond. FASEB J. 15: 1118-1131.

Råbergh, C.M., Airaksinen, S., Soitamo, A., Björklund, H.V., Johansson, T., Nikinmaa, M., and Sistonen, L. 2000. Tissuespecific expression of zebrafish (Danio rerio) heat shock factor 1 mRNAs in response to heat stress. J. Exp. Biol. 203: $1817-1824$.

Rabindran, S.K., Giorgi, G., Clos, J., and Wu, C. 1991. Molecular cloning and expression of a human heat shock factor HSF1. Proc. Nat1. Acad. Sci. 88: 6906-6910.

Rallu, M., Loones, M., Lallemand, Y., Morimoto, R., Morange, M., and Mezger, V. 1997. Function and regulation of heat shock factor 2 during mouse embryogenesis. Proc. Natl. Acad. Sci. 94: 2392-2397.

Ross, S., Tienhaara, A., Lee, M.S., Tsai, L.H., and Gill, G. 2002. GC box-binding transcription factors control the neuronal specific transcription of the cyclin-dependent kinase 5 regulator p35. J. Biol. Chem. 277: 4455-4464.

Sarge, K.D., Zimarino, V., Holm, K., Wu, C., and Morimoto, R.I. 1991. Cloning and characterization of two mouse heat shock factors with distinct inducible and constitutive DNA-binding ability. Genes \& Dev. 5: 1902-1911.

Sarge, K.D., Murphy, S.P., and Morimoto, R.I. 1993. Activation of heat shock gene transcription by heat shock factor 1 involves oligomerization, acquisition of DNA-binding activity, and nuclear localization and can occur in the absence of stress. Mol. Cell. Biol. 13: 1392-1407.

Schuetz, T.J., Gallo, G.J., Sheldon, L., Tempst, P., and Kingston, R.E. 1991. Isolation of a cDNA for HSF2: Evidence for two heat shock factor genes in humans. Proc. Natl. Acad. Sci. 88: 6911-6915.

Sistonen, L., Sarge, K.D., Phillips, B., Abravaya, K., and Morimoto, R.I. 1992. Activation of heat shock factor 2 during hemin-induced differentiation of human erythroleukemia cells. Mol. Cell. Biol. 12: 4104-4111.

Sistonen, L., Sarge, K.D., and Morimoto, R.I. 1994. Human heat shock factors 1 and 2 are differentially activated and can synergically induce Hsp70 gene transcription. Mol. Cell. Biol. 14: 2087-2099.

Takahashi, Y., Rayman, J.B., and Dynlacht, B.D. 2000. Analysis of promoter binding by the E2F and pRB families in vivo: Distinct E2F proteins mediate activation and repression. Genes \& Dev. 14: 804-816.

Theodorakis, N.G., Zand, D.J., Kotzbauer, P.T., Williams, G.T., and Morimoto, R.I. 1989. Hemin-induced transcriptional activation of the HSP70 gene during erythroid maturation in K562 cells is due to a heat shock factor-mediated stress response. Mol. Cell. Biol. 9: 3166-3173.

Tsai, L.H., Delalle, I., Caviness Jr., V.S., Chae, T., and Harlow, E. 1994. p35 is a neural-specific regulatory subunit of cyclindependent kinase 5. Nature 371: 419-423.

Wang, G., Zhang, J., Moskophidis, D., and Mivechi, N.F. 2003. Targeted disruption of the heat shock transcription factor (hsf)-2 gene results in increased embryonic lethality, neuronal defects, and reduced spermatogenesis. Genesis 36: 48-61.

Wilkinson, D.G. and Nieto, M.A. 1993. Detection of messenger RNA by in situ hybridization to tissue sections and whole mounts. Methods Enzymol. 225: 361-373.

Xiao, X., Zuo, X., Davis, A.A., McMillan, D.R., Curry, B.B., Richardson, J.A., and Benjamin, I.J. 1999. HSF1 is required for extra-embryonic development, postnatal growth and protection during inflammatory response in mice. $E M B O ~ J .18$ : 5943-5952.

Xing, H., Wilkerson, D.C., Mayhew, C.N., Lubert, E.J., Skaggs, H.S., Goodson, M.L., Hong, Y., Park-Sarge, O.-K., and Sarge, K.D. 2005. Mechanism of hsp70i gene bookmarking. Science 307: 421-423.

Yoshima, T., Yura, T., and Yanagi, H. 1998. Heat shock factor 1 mediates hemin-induced hsp70 gene transcription in K562 erythroleukemia cells. J. Biol. Chem. 273: 25466-25471.

Zhang, Y., Huang, L., Zhang, J., Moskophidis, D., and Mivechi, N.F. 2002. Targeted disruption of hsf1 leads to lack of thermotolerance and defines tissue-specific regulation for stressinducible Hsp molecular chaperones. J. Cell. Biochem. 86: 376-393. 


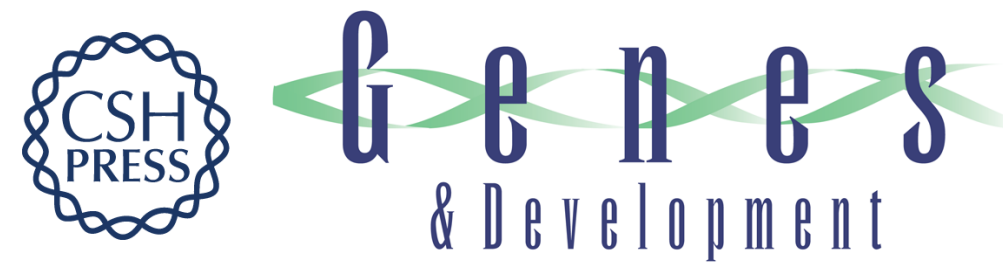

\section{Role of heat-shock factor 2 in cerebral cortex formation and as a regulatorof $\mathrm{p} 35$ expression}

Yunhua Chang, Päivi Östling, Malin Åkerfelt, et al.

Genes Dev. 2006, 20:

Access the most recent version at doi:10.1101/gad.366906

Supplemental http://genesdev.cshlp.org/content/suppl/2006/03/16/20.7.836.DC1
Material

References This article cites 69 articles, 33 of which can be accessed free at: http://genesdev.cshlp.org/content/20/7/836.full.html\#ref-list-1

License

Email Alerting

Receive free email alerts when new articles cite this article - sign up in the box at the top Service right corner of the article or click here.

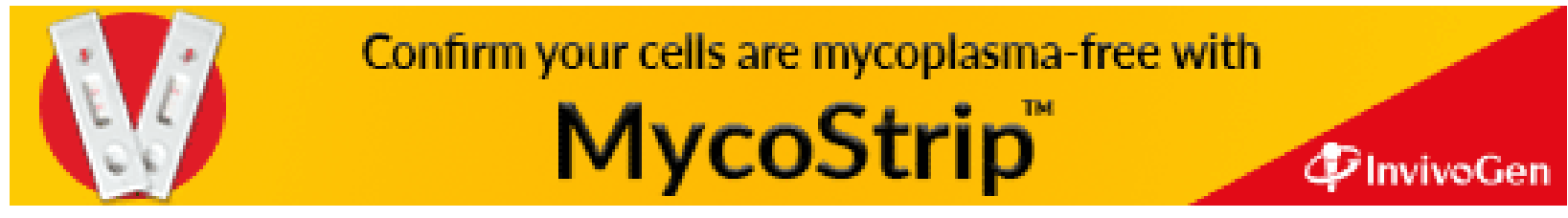

